\title{
Kemampuan Bakteri Endofit dalam Mengendalikan Penyakit Rebah Kecambah dan Layu Sclerotium (Sclerotium rolfsii) pada Kedelai
}

\author{
Endophytic Bacteria Ability in Controlling Damping Off and Sclerotium Wilt (Sclerotium \\ rolfsii) in Soybean \\ Husda Marwan ${ }^{1)^{*}}$, Sri Mulyati ${ }^{1}$, Weni Wilia ${ }^{1)}$ \\ 1) Program Studi Agroekoteknologi, Fakultas Pertanian Universitas Jambi, Kampus Pinang \\ Masak Jl. Jambi-Muara Bulian, Jambi 36361 \\ E-mail : husda_marwan@unja.ac.id
}

\begin{abstract}
Endophytic bacteria have potency as candidates of biological control agents to plant disease, because the bacteria as reported to be associated with plant resistance to pathogens. The study aimed to determine the ability of endophytic bacteria to inhibit the growth of Sclerotium rolfsii in vitro, and suppress damping off disease incedence and Sclerotium wilt disease severity on soybean. The ability of endophytic bacteria to inhibit $S$. rolfsii was carried out on 44 isolates that isolated from soybean, rice and banana. The ability of endophytic bacteria to control damping off disease was carried out on 13 isolates were selected in vitro (BE-CW1, BE-M1, BE-M2, BE-M3, BE-M4, BE-S1, BE-S6, BE-S13, BE-S14, BE $B R R G 2, B E-K H 1$ ), and also fungicides and two controls (healthy plant and diseased plant). The ability of endophytic bacteria to control Sclerotium wilt was carried out on 6 isolates which showed pressure on damping off disease (BE-M1, BE-M2, BE-M3, BE-M4, BE-CW1, BE$\mathrm{KH} 2$ ) and 2 controls (healthy plants and diseased plants). The results showed that the thirteen isolates of endophytic bacteria could inhibit mycelial growth and germination $S$. rolfsii. Soybean seed treatment revealed that dipping the seed in endophytic bacterial isolates suppressed damping off disease incedence with a range of 37.4 to $49.9 \%$ and Sclerotium wilt disease severity of 20.1 to $85 \%$, as well as reduced the mortality of soybean by 26.3 to $84.4 \%$. BE-KH2 isolate was able to suppress Sclerotium wilt in soybean by $85 \%$ and reduce the mortality by $67.5 \%$.
\end{abstract}

Keywords : endophytic bacteria, damping off, Sclerotium wilt, soybean

\section{PENDAHULUAN}

Cendawan Sclerotium rolfsii dapat menyebabkan penyakit rebah kecambah dan layu Sclerotium. Kehilangan hasil akibat serangannya dapat mencapai 30\% pada lahan-lahan yang selalu ditanami kedelai dan kacang-kacangan lainnya. Tingkat serangan $5 \%$ di lapangan, sudah dapat merugikan secara ekonomi (Sumartini, 2012). Menurut Sastrahidayat (2009), serangan $S$. rolfsii di daerah endemik dapat menurunkan produksi sekitar 25-55 $\%$.

Pengendalian hayati terhadap patogen tanaman dengan agensia hayati mempunyai prospek yang menjanjikan karena aman bagi lingkungan (Baker dan Cook, 1983). Salah satu agens pengendali hayati tersebut adalah bakteri endofit. Bakteri endofit dilaporkan menghasilkan antibiotik dan enzim pendegradasi yang 
dapat menghambat perkembangan patogen secara in vitro (Hallmann, 2001), serta meningkatkan ketahanan tanaman terhadap patogen dengan menginduksi reaksi ketahanan tanaman (Kloepper dan Ryu, 2006).

Menurut Ziedan (2006), kolonisasi bakteri endofit di dalam akar tanaman kacang tanah mampu menstimulasi reaksi pertahanan tanam-an kacang tanah terhadap infeksi cendawan Aspergillus niger dan Fusarium oxysporum. Bakteri endofit yang diisolasi dari Mucuna pruriens Linnaeus cenderung menekan penyakit bercak daun Cercospora dengan penekanan tertinggi sebesar 70,85 \% pada tanaman kacang tanah (Yulia et al., 2008). Hasil penelitian Sutariati dan Wahab (2010) menunjukkan bahwa bakteri endofit memiliki kemampuan menghambat pertumbuhan cendawan Colletroticum capsici dan Fusarium oxysporum secara in vitro serta berpotensi dikembangkan sebagai agensia hayati tanaman cabai.

Penelitian ini bertujuan untuk mengetahui kemampuan bakteri endofit dalam menghambat pertumbuhan miselia dan perkecambahan sklerotia dari cendawan S. rolfsii secara in vitro serta menganalisis kemampuan bakteri endofit dalam menekan kejadian penyakit rebah kecambah dan keparahan penyakit layu Sclerotium pada kedelai.

\section{METODOLOGI}

Penelitian ini telah dilaksanakan pada bulan Maret hingga bulan Desember 2013 di Laboratorium Proteksi Tanaman dan Kebun Percobaan Fakultas Pertanian Universitas Jambi.

\section{Uji penghambatan bakteri endofit}

Isolat bakteri endofit yang diuji adalah sebanyak 44 isolat yang diisolasi dari tanaman kedelai, padi dan pisang. Pengujian dilakukan dalam 2 tahap yaitu pengujian daya hambat terhadap pertumbuhan koloni $S$. rolfsii dan daya hambat terhadap perkecambahan sklerotia $S$. rolfsii.

Pengujian daya hambat bakteri endofit terhadap pertumbuhan koloni $S$. rolfsii dilakukan dengan mengkulturkan bakteri endofit dan $S$. rolfsii dalam satu cawan petri yang berisi media Potato Dextrose Agar (PDA). Biakan cendawan S. rolfsii diameter $0,5 \mathrm{~cm}$ diletakkan di tengah media PDA, kemudian isolat bakteri endofit digoreskan sepanjang $2 \mathrm{~cm}$ menggunakan jarum ose dengan jarak 3 $\mathrm{cm}$ dari biakan cendawan S. rolfsii. Biakan diinkubasikan pada suhu ruang selama 7 hari. Pengujian daya hambat bakteri endofit dinyatakan bernilai positif jika terdapat penekanan pertumbuhan koloni cendawan S. rolfsii pada cawan petri.

Pengujian daya hambat terhadap perkecambahan sklerotia S. rolfsii dilakukan dengan meletakkan sebanyak 5 sklerotia cendawan pada cawan petri berisi media PDA. Sebanyak 4 sklerotia disusun membentuk bujur sangkar dan bagian titik diagonalnya diletakkan satu sklerotia yang digunakan sebagai kontrol. Empat sklerotia diberi perlakuan dengan meneteskan $5 \mu \mathrm{l}$ suspensi bakteri endofit dari bagian atasnya, sedangkan satu sklerotia sebagai kontrol ditetesi dengan $5 \mu \mathrm{l}$ air steril. Biakan diinkubasikan pada suhu ruang selama 7 hari. Pengujian daya hambat bakteri endofit dinyatakan bernilai positif jika terdapat penghambatan perkecambahan sklerotia cenda-wan S. rolfsii.

\section{Uji kemampuan bakteri endofit untuk mengendalikan penyakit rebah kecambah \\ Pengujian menggunakan Ran-} cangan Acak Lengkap (RAL) dengan 15 perlakuan. Perlakuan terdiri dari 13 perlakuan isolat bakteri endofit yang telah diseleksi secara in vitro (Isolat BE-CW1, BE-M1, BE-M2, BE-M3, BE-M4, BE-S1, BES6, BE-S13, BE-S14, BE-BRRG2, BE-KH1), perlakuan fungisida sintetik dan kontrol tanaman sakit). Setiap perlakuan diulang 
Marwan et al. Kemampuan Bakteri Endofit

sebanyak 5 kali, sehingga terdapat 75 satuan percobaan.

Media tanam yang digunakan adalah campuran tanah dan pupuk kandang yang disterilkan dengan perbandingan 1:1. Infestasi patogen dilakukan dengan cara mencampurkan $50 \mathrm{~g}$ biakan corn meal sand (CMS) dari $S$. rolfsii ke dalam setiap polibag yang berisi $5 \mathrm{~kg}$ media tanam, lalu diaduk dan diinkubasikan selama 2 minggu.

Aplikasi bakteri endofit pada benih kedelai dilakukan dengan cara merendam benih kedelai dalam $100 \mathrm{ml}$ suspensi isolat bakteri endofit dengan populasi $10^{8}-10^{9}$ $\mathrm{cfu} / \mathrm{ml}$ selama 30 menit. Sebanyak 10 benih kedelai ditanam dalam masingmasing polibag kemudian permukaan tanah disemprot dengan $10 \mathrm{ml}$ suspensi bakteri endofit.

Pengamatan dimulai sejak hari pertama dilakukan penanaman sampai tanaman berumur 2 minggu. Kecambah yang tidak muncul dilakukan pembongkaran dan persentase preeemergence damping off diperoleh dengan menggunakan rumus:

$S=\frac{(A-B)}{A} \times 100 \%-(100 \%-D)$

Keterangan :

$\mathrm{S}=$ Jumlah kecambah terserang sebelum muncul ke permukaan tanah (PreeEmergence Damping-Off) (\%)

$A=$ Jumlah benih yang ditanam

$B=$ Jumlah kecambah yang muncul ke permukaan tanah

$\mathrm{D}=$ Persentase daya kecambah

Persentase penekanan penyakit busuk pangkal batang dihitung dengan menggunakan rumus sebagai berikut:

$\mathrm{Pi}=100 \%-\frac{\mathrm{Xi}}{\mathrm{I}} \times 100 \%$

Keterangan :

$\mathrm{Pi}=$ Persentase penekanan penyakit pada perlakuan $\mathrm{i}$
$\mathrm{Xi}=$ Persentase penyakit pada perlakuan i

I =Persentase penyakit pada perlakuan kontrol tanaman sakit

Data hasil pengamatan periode inkubasi penyakit dianalis secara deskriptif, sedangkan untuk pengaruh isolat bakteri endofit terhadap persentase penyakit rebah kecambah dianalisis dengan menggunakan analisis ragam dan dilanjutkan dengan uji Dunnet pada taraf $5 \%$.

\section{Uji kemampuan bakteri endofit untuk} mengendalikan penyakit layu Sclerotium

Penelitian menggunakan Rancangan Acak Lengkap (RAL) dengan 8 perlakuan. Perlakuan terdiri dari 6 isolat bakteri endofit yang menunjuk-kan penekanan terhadap penyakit rebah kecambah (isolat BE-M1, BE-M2, BE-M3, BE-M4, BECW1, BE-KH2) dan 2 perlakuan sebagai kontrol (tanaman sehat, tanaman sakit). Setiap perlaku-an diulang sebanyak 10 kali, sehingga terdapat 80 satuan percobaan.

Benih kedelai direndam dalam 100 $\mathrm{ml}$ suspensi isolat bakteri endofit dengan kerapatan populasi $10^{8}-10^{9} \mathrm{cfu} / \mathrm{ml}$ selama 30 menit. Sebanyak 10 benih kedelai ditanam dalam polibag kemudian permukaan tanah disemprot dengan sisa suspensi bakteri hasil perendaman benih kedelai. Setelah bibit berumur 1 minggu, dilakukan penjarangan dengan meninggalkan 3 tanaman/polibag.

Inokulasi cendawan $S$. rolfsii ke pangkal batang tanaman dilakukan 2 minggu setelah tanam. Inokulasi dilakukan dengan cara menempelkan biakan $S$. rolfsii sebesar $3 \times 3 \mathrm{~cm}$ ke pangkal batang tanaman lalu ditutup dengan kapas yang telah dilembabkan dan diikat dengan selotip.

Parameter pengamatanan adalah periode inkubasi penyakit, intensitas penyakit busuk pangkal batang, lama tanaman mati dan persentase tanaman 
mati. Intensitas penyakit diamati dengan mengukur keliling batang bergejala. Intensitas penyakit dihitung dengan rumus :

$I P=\frac{K}{T k} \times 100$

Keterangan:

I $p=$ Intensitas penyakit

$\mathrm{K}=$ Keliling batang bergejala

$\mathrm{Tk}=$ Total keliling batang

Data hasil pengamatan tentang periode inkubasi penyakit dianalis secara deskriptif, sedangkan pengaruh isolat bakteri endofit terhadap persentase penyakit dan intensitas penyakit dianalisis dengan mengguna-kan analisis ragam dan dilanjutkan dengan uji DNMRT (Duncan News Multiple Range Test) dengan menggunakan Statistical Package for Social (SPSS).

\section{HASIL}

Penghambatan bakteri endofit terhadap Sclerotium rolfsii

Hasil pengujian uji antibiosis isolat bakteri endofit terhadap pertumbuhan koloni cendawan $S$. rolfsii menunjukan bahwa terdapat 26 isolat bakteri endofit yang mampu menghambat pertumbuhan koloni cendawan S. rolfsii dan 13 isolat diantaranya mampu menghambat perkecambahan sklerotia cendawan $S$. rolfsii (Tabel 1).

Persentase kecambah terserang sebelum muncul ke permukaan tanah (preeemergence damping-off)

Aplikasi bakteri endofit pada benih kedelai tidak memberikan pengaruh terhadap persentase damping off dibandingkan kontrol sakit. Serangan terendah terjadi pada perlakuan pemberian isolat BE-M2 dengan rata-rata persentase serangan sebesar $15,37 \%$ dan penekanan penyakit sebesar 49,97 \% (Tabel 2).

Tabel 1. Aktivitas penghambatan bakteri endofit terhadap pertumbuhan koloni dan perkecambahan sklerotia S. rolfsii

\begin{tabular}{clcc}
\hline No. & Kode isolat bakteri endofit & $\begin{array}{c}\text { Penghambatan pertumbuhan } \\
\text { koloni S. rolfsii }\end{array}$ & $\begin{array}{c}\text { Penghambatan perkecambahan } \\
\text { sklerotia S. rolfsii }\end{array}$ \\
\hline 1 & BE-CW1 & + & + \\
2 & BE-CW2 & - & - \\
3 & BE-CW3 & - & - \\
4 & BE-CW4 & + & - \\
5 & BE-BRRG1 & + & - \\
6 & BE-BRRG2 & - & + \\
7 & BE-BRRG3 & + & - \\
8 & BE-SLWH1 & + & - \\
9 & BE-SLWH2 & - & - \\
10 & BE-TGMS1 & + & - \\
11 & BE-TGMS2 & + & + \\
12 & BE-TGMS3 & + & + \\
13 & BE-KH1 & + & - \\
14 & BE-KH2 & - & + \\
15 & BE-KH3 & + & - \\
16 & BE-KH4 & - & - \\
17 & BE-KR1 & - & - \\
18 & BE-KR2 & + & - \\
19 & BE-KR3 & + & + \\
20 & BE-KR5 & + & + \\
21 & BE-M1 & + & + \\
22 & BE-M2 & & + \\
\hline
\end{tabular}




\begin{tabular}{llll}
\hline 23 & BE-M3 & + & + \\
24 & BE-M4 & + & + \\
25 & BE-M5 & + & - \\
26 & BE-M6 & + & - \\
27 & BE-M7 & - & - \\
28 & BE-S1 & + & + \\
29 & BE-S2 & - & - \\
30 & BE-S3 & + & - \\
31 & BE-S4 & - & - \\
32 & BE-S5 & + & + \\
33 & BE-S6 & + & - \\
34 & BE-S7 & - & - \\
35 & BE-S8 & + & - \\
36 & BE-S10 & - & - \\
37 & BE-S11 & - & + \\
38 & BE-S12 & - & + \\
39 & BE-S13 & + & - \\
40 & BE-S14 & + & - \\
41 & BE-EAL15 & + & - \\
42 & BE-EKK10 & - & - \\
43 & BE-EKK20 & - & - \\
44 & BE-EKK22 & - & - \\
\hline
\end{tabular}

Keterangan: + = Terjadi aktivitas penghambatan; - = Tidak terjadi aktivitas penghambatan

Tabel 2. Persentase pree-emergence damping-off

\begin{tabular}{lcc}
\hline Perlakuan pemberian isolat & $\begin{array}{c}\text { Rata-rata kecambah } \\
\text { terserang (\%) }\end{array}$ & $\begin{array}{c}\text { Penekanan } \\
\text { penyakit (\%) }\end{array}$ \\
\hline Tanaman sakit (K1) & 30,72 & - \\
Fungisida (K2) & 07,71 & 74,91 \\
BE-CW1 & 15,39 & 49,91 \\
BE-M1 & 19,22 & 37,44 \\
BE-M2 & 15,37 & 49,97 \\
BE-M3 & 19,22 & 37,44 \\
BE-M4 & 19,22 & 37,44 \\
BE-S1 & 49,92 & $*$ \\
BE-S6 & 38,41 & $*$ \\
BE-S13 & 38,41 & $*$ \\
BE-S14 & 38,40 & $*$ \\
BE-BRRG2 & 34,56 & $*$ \\
BE-KH1 & 30,72 & $*$ \\
BE-KH2 & 19,22 & 37,44 \\
BE-KH4 & 42,24 & $*$ \\
\hline Ket: Rata-rape
\end{tabular}

Ket: $\quad$ Rata-rata perlakuan tidak berbeda nyata pada pembanding K1 (tanaman sakit)

* = Tidak terjadi penekanan penyakit

\section{Periode inkubasi penyakit layu Sclerotium}

Aplikasi bakteri endofit pada benih tanaman kedelai berpengaruh terhadap periode inkubasi penyakit layu Sclerotium. Berdasarkan data periode inkubasi penyakit layu Sclerotium bahwa gejala awal penyakit layu Sclerotium muncul 1718 hst pada kontrol K1, dimana 20 tanaman menunjukkan gejala penyakit layu Sclerotium. Pemberian isolat BE-KH2 paling lama memperpanjang periode 
inkubasi penyakit layu Sclerotium (19-32 hst), dengan jumlah tanaman bergejala penyakit layu Sclerotium sebanyak 3 tanaman (Tabel 3).

Tabel 3. Periode inkubasi penyakit layu sclerotium pada tanaman kedelai

\begin{tabular}{lcc}
\hline \multicolumn{1}{c}{ Perlakuan } & Periode Inkubasi & Jumlah tanaman bergejala \\
\hline Tanaman sehat (K1) & $*$ & $*$ \\
Tanaman sakit (K2) & $17-18$ hst & 20 tanaman \\
BE-CW1 & $18-30$ hst & 12 tanaman \\
BE-M1 & $18-31$ hst & 16 tanaman \\
BE-M2 & $18-30$ hst & 13 tanaman \\
BE-M3 & $18-31$ hst & 12 tanaman \\
BE-M4 & $17-30$ hst & 14 tanaman \\
BE-KH2 & $19-32$ hst & 3 tanaman \\
\hline
\end{tabular}

Keterangan: ${ }^{*}=$ tidak muncul gejala penyakit; hst $=$ hari setelah tanam

\section{Intensitas penyakit layu Sclerotium}

Hasil analisis ragam menunjukkan bahwa aplikasi isolat bakteri endofit pada benih kedelai berpengaruh terhadap intensitas penyakit layu Sclerotium. Apli- kasi isolat bakteri endofit BE-CW1, BE-M2, $\mathrm{BE}-\mathrm{M} 3, \mathrm{BE}-\mathrm{M} 4, \mathrm{BE}-\mathrm{KH} 2$ mampu menurunkan intensitas penyakit layu Sclerotium pada 21, 28, dan 35 hst (Tabel 3).

Tabel 3. Intensitas penyakit Sclerotium tanaman pada kedelai

\begin{tabular}{cccc}
\hline \multirow{2}{*}{ Perlakuan } & \multicolumn{3}{c}{ Intensitas penyakit layu Sclerotium (\%) } \\
\cline { 2 - 4 } & $21 \mathrm{hst}$ & $28 \mathrm{hst}$ & $35 \mathrm{hst}$ \\
\hline Tanaman sehat (K1) & $0 \mathrm{c}$ & $0 \mathrm{c}$ & $0 \mathrm{c}$ \\
Tanaman sakit (K2) & $71,8 \mathrm{a}$ & $76,7 \mathrm{a}$ & $76,7 \mathrm{a}$ \\
BE-CW1 & $38,1 \mathrm{~b}$ & $40,0 \mathrm{~b}$ & $40 \mathrm{~b}$ \\
BE-M1 & $50,3 \mathrm{a}$ & $51,4 \mathrm{~b}$ & $53,3 \mathrm{~b}$ \\
BE-M2 & $37,8 \mathrm{~b}$ & $40,7 \mathrm{~b}$ & $43,3 \mathrm{~b}$ \\
BE-M3 & $38,3 \mathrm{~b}$ & $40,7 \mathrm{~b}$ & $40 \mathrm{~b}$ \\
BE-M4 & $36,0 \mathrm{~b}$ & $43,7 \mathrm{~b}$ & $43,3 \mathrm{~b}$ \\
BE-KH2 & $9,0 \mathrm{bc}$ & $10,0 \mathrm{bc}$ & $10,0 \mathrm{bc}$ \\
\hline
\end{tabular}

Keterangan : Angka pada tiap kolom yang diikuti dengan huruf sama tidak berpengaruh nyata menurut uji DNMRT taraf 5\%; hst = hari setelah tanam

\section{Persentase penyakit layu Sclerotium}

Aplikasi bakteri endofit dengan berbagai sumber isolat mampu menurunkan jumlah tanaman yang terserang cendawan S. rolfsii pada 35 hst, dengan persentase penekanan sebesar 20,09 $85,00 \%$. Aplikasi beberapa isolat bakteri endofit memperlambat terjadinya kematian tanaman 1-2 hari dan menurunkan jumlah tanaman kedelai yang mati. Tanaman kontrol (K2) mati pada hari ketiga, sedangkan tanaman yang diaplikasi dengan isolat $\mathrm{BE}-\mathrm{CW} 1, \mathrm{BE}-\mathrm{M} 2$, dan BE$\mathrm{KH} 2$ mati pada hari keempat dan kelima. Persentase tanaman mati pada perlakuan aplikasi bakteri endofit berkisar 12,5 $59 \%$, sedangkan pada tanaman kontrol (K2) mencapat 80\% (Tabel 4).

Tabel 4. Pengaruh perlakuan bakteri endofit terhadap perkembangan penyakit layu Sclerotium pada tanaman kedelai

\begin{tabular}{ccccc}
\hline & Jumlah tanaman & Penekanan & Lama & Persentase \\
Perlakuan & sakit pada 35 hst & $\begin{array}{c}\text { penyakit } \\
\text { tanaman }\end{array}$ & tanaman \\
& $(\%)$ & $(\%)$ & mati (hari) & mati (\%) \\
\hline
\end{tabular}


Marwan et al. Kemampuan Bakteri Endofit

\begin{tabular}{lcccc}
\hline Tanaman sehat (K1) & $0,00 \mathrm{c}$ & 0,0 & 0,0 & 0 \\
Tanaman sakit (K2) & $66,7 \mathrm{a}$ & 0,0 & 3,0 & 80 \\
BE-CW1 & $40,0 \mathrm{~b}$ & 40,0 & 4,0 & 46 \\
BE-M1 & $53,3 \mathrm{~b}$ & 20,1 & 3,0 & 59 \\
BE-M2 & $43,3 \mathrm{~b}$ & 35,1 & 4,0 & 48 \\
BE-M3 & $40,0 \mathrm{~b}$ & 40,0 & 3,0 & 52 \\
BE-M4 & $46,6 \mathrm{~b}$ & 30,1 & 3,0 & 50 \\
BE-KH2 & $10,0 \mathrm{bc}$ & 85,0 & 5,0 & 12,5 \\
\hline
\end{tabular}

Keterangan: hst $=$ hari setelah tanam

\section{PEMBAHASAN}

Berdasarkan pengamatan terhadap aktivitas penghambatan bakteri endofit yang menunjukan reaksi antibiosis yaitu isolat BE-KH1, BE-KH2, BE-KH4, BEKR3, BE-KR5, BE-CW1, BE-M1, BE-M2, BEM3, BE-M4, BE-M5, BE-M6, BE-S1, BE-S1, BE-S5, BE-S6, BE-S8, BE-S13, BE-S14, BEEAL15, BE-BRRG1, BE-BRRG2, BE-SLWH1, BE-SLWH2, BE-TGMS2 dan BE-TGMS3. Isolat tersebut mampu menekan pertumbuhan koloni cendawan $S$. rolfsii yang ditandai dengan terciptanya zona bening. Melliawati (2006) menyatakan bahwa zona bening yang tercipta antara dua koloni pada cawan petri merupakan sebuah tanda adanya senyawa aktif yang dihasilkan oleh bakteri endofit dan mampu menghambat pertumbuhan mikroba patogen. Eliza et al., (2007) menambahkan bahwa senyawa ini disebut dengan senyawa anti jamur, yang secara umum mengakibatkan terjadinya pertumbuhan abnormal pada hifa, yang ditunjukan dengan pembengkakan dan pemendekan hifa, mengakibatkan hifa tidak dapat berkembang dengan sempurna.

Selain menekan pertumbuhan koloni S. rolfsii, terdapat bakteri endofit yang mampu menghambat perkecambahan sklerotia dari $S$. rolfsii yaitu isolat BE-KH1, BE-KH2, BE-KH4, BE-CW1, BE-M1, BE-M2, BE-M3, BE-M4, BE-S1, BE-S6, BES13, BE-S14 dan BE-BRRG2. Hasil penelitan Munif et al. (2012) menyatakan bahwa beberapa bakteri endofit yang berasal dari tanaman padi gogo menunj- ukan reaksi antibiosis terhadap patogen Ralstonia solanacearum dan Pyricularia grisea. Menurut Baker dan Cook (1983), mikroba antagonis mampu mensekresikan kultur fitrat berupa senyawa antibiotik, bakteriosin dan spora. Beberapa isolat bakteri endofit tidak menunjukan reaksi antibiosis terhadap cendawan $S$. rolfsii. Perbedaan keefektifan penghambatan tersebut disebabkan oleh perbedaan mekanisme kerja antimikroba yang disekresikan oleh bakteri endofit tersebut (Sutariati dan Wahab, 2010).

Potensi isolat bakteri endofit tersebut bervariasi. Berdasarkan hasil penelitian ini diperoleh isolat bakteri endofit yang menunjukan kemampuannya dalam menekan penyakit preeemergence damping-off yaitu bakteri endofit dengan kode isolat $B E-C W 1, B E-$ M1, BE-M2, BE-M3, BE-M4 dan BE-KH2 dengan besar penekanan persentase penyakit sebesar 37,44 - 49,97 \%. Persentase pree-emergence damping-off terendah terjadi pada perlakuan dengan pemberian bakteri endofit dengan kode isolat BE-M2 yaitu sebesar 15,37 \% dengan penekanan penyakit sebesar $49,97 \%$.

Hasil penelitian sebelumnya melaporkan bahwa bakteri endofit dalam tanaman inang Spilanthes calva mampu memproduksi senyawa alkaloid yang berperan menghambat serangan patogen tular tanah (Rai et al., 2002). Selain itu bakteri endofit juga mampu mensekresikan berbagai macam enzim, seperti enzim kitinase yang mampu mendeg- 
radasi kitin yang merupakan komponen dinding sel pada cendawan patogen Rhizoctonia solani, F. oxysporum dan S. rolfsii (Raaijmaker et al., 2008). Kageyama et al. (2008) menambahkan bahwa bakteri endofit mampu melindungi inang dari serangan patogen dengan menghasilkan senyawa kimia yang mampu menghambat serangan patogen.

Berdasarkan hasil penelitian secara in vitro dan in planta menunjukkan hasil bahwa terdapat isolat bakteri endofit yang menunjukan reaksi antibiosis terhadap cendawan $S$. rolfsii tetapi tidak menunjukan adanya penekanan penyakit pree-emergence damping-off secara in planta. Hal ini terjadi pada isolat bakteri endofit dengan kode isolat BE-S1, BE-S6, BE-S13, BE-S14, BE-BRRG2, BE-KH1, dan $\mathrm{BE}-\mathrm{KH} 4$. Adanya perlakuan pemberian bakteri endofit yang tidak memberikan penekanan terhadap penyakit rebah kecambah ini diduga karena terjadi interaksi yang bersifat netral diantara keduanya. Menurut Hallman (2001) terdapat tiga bentuk interaksi antara bakteri endofit dan tanaman inangnya, yaitu: 1. Netralisme, dimana tidak terdapat efek diantara keduanya; 2. Mutualisme, dimana kedua komponen mendapatkan keuntungan; dan 3. Komensalisme, dimana salah satu pihak mendapatkan keuntungan dari interaksi yang terjadi dan pihak yang lain tidak mendapatkan efek apapun.

Salah satu faktor yang menentukan tingkat keefektifan bakteri endofit dalam menekan persentase penyakit yaitu kemampuan beradaptasi terhadap lingkungan barunya. Kemampuan kompetisi isolat bakteri endofit yang terbiasa dibiakkan di laboratorium dengan patogen yang telah berada dalam tanah cenderung rendah sehingga berpengaruh terhadap tingkat kefektifan pengendalian. Menurut Waller (1988) dalam Yulianti (2013) agen pengendali hayati sering tidak mampu beradaptasi di lingkungan yang baru atau kurang mampu bersaing dengan mikroorganisme yang telah lama menghuni lingkungan tersebut.

Aplikasi bakteri endofit BE-KH2 dan BE-M4 menunjukkan gejala penyakit layu muncul lebih lama (Tabel 3). Perbedaan munculnya gejala penyakit pada tanaman yang diberi perlakuan bakteri endofit dapat terjadi karena bakteri mampu menghambat proses penetrasi cendawan pada jaringan tanaman. Menurut van Loon et al. (1998), kemampuan bakteri endofit dalam menginduksi ketahanan tanaman terjadi melalui cara penebalan dinding sel dan secara kimiawi meningkatkan senyawa fenol dan fitoaleksin, sehingga menghambat proses penetrasi patogen ke dalam jaringan tanaman. Hal ini dapat mengakibatkan munculnya gejala awal serangan patogen menjadi lebih lama.

Pengamatan terhadap intensitas penyakit layu Sclerotium pada 21 hst menunjukkan bahwa semua perlakuan berpengaruh terhadap intensitas penyakit dibandingkan dengan tanaman kontrol, kecuali pada perlakuan BE-M1. Pada pengamatan 28 dan 35 hari setelah tanam menunjukkan bahwa semua perlakuan bakteri endofit mampu menekan intensitas penyakit layu Sclerotium pada Tanaman kedelai (Tabel 3). Menurut Rosenblueth dan Esperanza (2006), keberadaan bakteri endofit dapat mempengaruhi gen-gen tanaman dan ekspresi dari gen-gen ketahanan terhadap penyakit pada tanaman.

Berdasarkan persentase penyakit layu Sclerotium, lama tanaman mati dan persentase tanaman mati dapat dilihat bahwa aplikasi bakteri endofit pada benih kedelai mampu menekan perkembangan penyakit layu Sclerotium. Perlakuan isolat bakteri endofit BE-KH2 menunjukkan persentase tanaman terserang dan persentase tanaman mati terendah dan 
Marwan et al. Kemampuan Bakteri Endofit

penekanan penyakit paling tinggi dibandingkan dengan perlakuan lainnya. Perlakuan BE-KH2 mampu menekan penyakit layu Sclerotium pada tanaman kedelai sebesar $85 \%$ dan menurunkan persentase tanaman mati sebesar $67,5 \%$ (Tabel 4). Munif et al. (2012) menyatakan bahwa bakteri endofit mampu meningkatkan sistem pertahanan tanaman terhadap gangguan penyakit tanaman karena kemampuannya untuk memproduksi senyawa antimikroba, enzim, asam salisilat, etilena dan senyawa sekunder lainnya yang berperan dalam menginduksi ketahanan tanaman. Menurut Silva et al. (2004), tingginya aktivitas peroksidase yang dihasilkan bakteri endofit dapat menghambat proses infeksi patogen karena terjadinya lignifikasi dan pembentukan hidrogen peroksida yang menghambat patogen secara langsung atau pembentukan radikal bebas yang mempunyai efek anti mikroba. Peroksidase berperan sebagai katalis dalam polimerasi monolignols (alkohol p-caumaryl, coniferyl, dan sinapyl) yang membangun lignin (Vickery dan Brian 1981; Vidhyasekaran 2004).

\section{KESIMPULAN}

Isolat bakteri endofit mampu menghambat pertumbuhan koloni perkecambahan sklerotia cendawan S. rolfsii. Aplikasi bakteri endofit pada benih kedelai mampu memperlambat munculnya gejala, menekan kejadian penyakit damping off dengan kisaran 37,4 - 49,9\% dan menekan keparahan penyakit layu Sclerotium sebesar 20,1 - 85\%, serta mengurangi kematian kedelai sebesar 26,3 - 84,4\%. Isolat $\mathrm{BE}-\mathrm{KH} 2$ mampu menekan penyakit layu Sclerotium sebesar $85 \%$ dan menurunkan kematian tanaman kedelai sebesar $67,5 \%$.

\section{DAFTAR PUSTAKA}

Baker KF dan RJ Cook. 1983. Biological control of plant pathogens. W. H.
Freeman and Company, San Fransisco.

Eliza A Munif, I Djatnika dan Widodo. 2007. Karakter fisiologis dan peranan antibiosis bakteri perakaran graminae terhadap fusarium dan pemacu pertumbuhan tanaman pisang. Jurnal Hortikultura 17(2): 150-160.

Hallmann J. 2001. Plant interaction with endophytic bacteria. dalam: Jeger MJ and NJ Spence (eds.). Biotic interaction in plant-pathogen associations. CABI Publising.

Kageyama SA, KG Mandyam dan A Jumpponen. 2008. Diversity, function and potential applications of the root-associated endophytes. Kansas State University. Manhattan.

Kloepper JW dan Ryu CM. 2006. Bacterial endophytes as elicitors of induced systemic resistance. In: Schulz B, Boyle C, Sieber TN. Editor. Microbial Root Endophytic. Springer-Verlag Berlin Heidelberg. pp.33-43.

Melliawati R, DN Widyaningrum, AC Djohan dan H Sukiman. 2006. Pengkajian bakteri endofit penghasil senyawa bioaktif untuk proteksi tanaman. Biodiversitas 7(3): 221224.

Munif A, S Wiyono dan Suwarno. 2012. Isolasi bakteri endofit asal padi gogo dan potensinya sebagai agens biokontrol dan pemacu pertumbuhan. Jurnal Fitopatologi Indonesia 8(3): 57-64.

Raaijmaker JM, TC Paulitz, CAZ Steinberg dan LY Moenne. 2008. The rhizosphere: a playground and battlefield for soilborne pathogens and beneficial microorganism. Plant Soil 321 (1): 341-361.

Rai MK, A Varma dan AK Pandey. 2002. Antifungal potential of Spilanthes calva after inoculation of 
Piriformospora indica. Mycoses (47): 479-481.

Rosenblueth M dan MR Esperanza. 2006. Bacterial endophytes and their interactions with hosts. Rev The American Phytopathol Society 19 : pp. 827-837.

Sastrahidayat IR. 2009. Rekayasa teknologi peningkatan produksi kedelai dan pengendalian penyakit rebah semai dengan pemupukan campuran secara hayati. Laporan Hasil Penelitian. Hibah Kompetensi. Universitas Brawijaya.

Silva HSA, RS Romeiro dan Macagnan D. 2004. Rhizobacterial induction of systemic resistance in tomato plants: non-specific protection and increase in enzyme activities. Biological Control 29:288-295.

Sumartini. 2012. Penyakit tular tanah Sclerotium rolfsii dan Rhizoctonia solani pada tanaman kacangkacangan dan umbi-umbian serta cara pengendaliannya. Jurnal Litbang Pertanian 31 (1): 27-34.

Sutariati GAK dan A Wahab. 2010. Isolasi dan uji kemampuan rizobakteri indigenous sebagai agensia pengendali hayati penyakit pada tanaman cabai. Jurnal Hortikultura 20 (1): 86-95. van Loon LC, PAHM Bakker dan CMJ Pieterse. 1998. Systemic resistance induced by rhizosphere bacteria. Annu Rev Phytopathol. 36: 453-483.

Vickery ML dan V Brian. 1981. Secondary plant metabolism. The MacMillan Press LTD. London.

Vidhyasekaran P. $2004 . \quad$ Concise Enclyclopedia of plant pathology. Food Product Press and Howard Reference Press. London.

Yulia E, F Widiantini, F Firmansyah, dan A Karuniawan. 2008. Kemampuan ekstrak dan inhabitan Mucuna pruriens linn. dalam menekan penyakit bercak dauncercospora dan meningkatkan pertumbuhan tanaman kacang tanah. Jurnal Agrikultura 19 (1): 50-59.

Yulianti T. 2013. Pemanfaatan endofit sebagai agensia pengendali hayati hama dan penyakit tanaman. Buletin Tanaman Tembakau, Serat \& Minyak Industri 5 (1): 40-49.

Ziedan EHE. 2006. Manipulating endophytic bacteria for biological control to soil borne diseases of peanut. Journal of Applied Sciences Research 2(8): 497-502. 